\title{
FORMS OF AUTHORITY BEYOND THE NEOLIBERAL STATE: SOVEREIGNTY, POLITICS AND AESTHETICS
}

\author{
CHRIS BUTLER AND KAREN CRAWLEY'
}

\begin{abstract}
Critical legal scholarship has recently turned to consider the form, mode and role of law in neoliberal governance. A central theme guiding much of this literature is the importance of understanding neoliberalism as not only a political or economic phenomenon, but also an inherently juridical one. This article builds on these conceptualisations of neoliberalism in turning to explore the wider historical, cultural and sociological contexts which inform the production of neoliberal authority. The papers in this collection were first presented at the symposium 'Forms of authority beyond the neoliberal state', held at the Griffith Law School in December 2017. They consider the role of the corporation, the site of the university, the politics of debt, the genre of prestige television, and the archic sources of state violence, in order to imagine forms of authority which lie beyond neoliberalism as an ideology and a set of practices, and the neoliberal state as an ensemble of institutions. The contributions draw on social theory, philosophy, cultural studies, legal geography and political theology in exploring new possibilities for cultivating judgement through and beyond the sovereign, political and aesthetic terrains of neoliberal governance.
\end{abstract}

KEYWORDS. Aesthetics, authority, neoliberalism, politics, sovereignty, state power.

Since the late 1970s forms of neoliberal governance have achieved a dominant status across the globe, and have been justified on the basis that they are capable of delivering a socially beneficial and stable system of economic regulation. While there is ongoing debate about its precise definition, or even its utility as an explanatory concept (Barnett 2010), neoliberalism is usually understood as referring to institutional arrangements which are oriented towards liberalised and deregulated markets, the privatisation of public assets, and the prioritisation of private property rights (Boltanski and Chiapello 2005; Bourdieu 1998; Duménil and Lévy 2004; Gilbert 2013; Harvey 2005; Peck 2010; Plant 2010; Springer et.al., 2016). However the state has played a crucial role in the design and implementation of processes of neoliberalisation, and a growing body of scholarship is now recognising that the dynamics of neoliberal governance cannot be adequately understood along the lines of the classical liberal formulation of the 'nightwatchman state' (Brown 20I5; Cahill 20I4; Dardot and Laval 20I4; Davies, 20I4; Mirowski 2009; Peck and Tickell 2002). On the contrary, neoliberalism is premised on the importance of a strong state,

\footnotetext{
I Chris Butler, Griffith Law School, Griffith University, Nathan, Queensland, Australia, 4I I I, Email: c.butler@griffith.edu.au

Karen Crawley, Griffith Law School, Griffith University, Nathan, Queensland, Australia, 4III

Email: k.crawley@griffith.edu.au
} 
a state 'restructured ... rather than restrained' (Brabazon 2017a: 5). Just as neoliberal states have sought to deregulate and liberalise their economies, they have been intimately involved in imposing the logic of the market on areas of decision-making and service delivery which had previously been guided (however inadequately) by principles of the public good (Honig 2013). In addition, the domains of state intervention in private and public life have steadily extended, as seen, for example, in regimes of income management and mutual obligation, increasing prison populations and the encroachments of techniques of surveillance and security (Passavant 2005; Peck 200I; Wacquant 2009).

Critical legal scholarship has recently turned to consider the form, mode and role of law in neoliberal governance (Brabazon 2017b; Golder and McLoughlin 2018). A central theme guiding the contributions to each of these edited volumes is the importance of understanding neoliberalism as not only a political or economic phenomenon, but also an inherently juridical one. The essays in Brabazon's collection explore how ideals such as the rule of law, formal equality and freedom of contract work alongside inevitable instances of legal indeterminacy to shore up aspects of the neoliberal project and to oppose collective forms of resistance to its modes of governance. As Brabazon argues

neoliberalism as an ideological and theoretical project can be seen as the creation of a particular kind of society and subjectivity rooted in a very limited conception of individuality, democracy, and social life, in which public debate and dissent are minimal and contained, collective action discouraged, and substantive inequalities are ignored or celebrated as convenient. (Brabazon 20I7a, p. 12)

The interpretations of neoliberalism that are offered by the authors of both these books traverse three theoretical schools of thought. These include the self-understanding of neoliberal doctrines by those involved in their development, such as European ordoliberalism and the Chicago School in the United States; a Marxist political economy approach which places neoliberalism firmly within the context of the dominant role of financial capital since the 1970s; and a Foucauldian-inspired understanding of neoliberalism as a form of governmental rationality which is productive of particular subjectivities and social relations. In recent years Foucault's understanding of neoliberalism as a form of rationality of governance that produces new kinds of political subjects and a new organisation of the social realm has proved very influential as a way of challenging both the limitations of orthodox Marxist accounts and the ideological presentation of neoliberalism by its advocates (Rose 1996; Rose, O'Malley, Valverde 1996). Rejecting understandings of neoliberalism as 'a set of state policies, a phase of capitalism, or an 
ideology that set loose the market', Wendy Brown joins Foucault in understanding neoliberalism as 'an order of normative reason that, when it becomes ascendant, takes shape as a governing rationality extending a specific formulation of economic values, practices and metrics to every dimension of human life' (Brown 20I5, p. 30). She writes that neoliberal rationality 'disseminates the model of the market to all domains and activities ... and configures human beings exhaustively as market actors, always, only, and everywhere as homo oeconomicus' (Brown 20I5, p. 3I).

This special issue builds on the conceptualisations of neoliberalism that have drawn from these three theoretical lenses, while also moving to consider wider historical, cultural and sociological factors such as the role of the corporation, the site of the university, the politics of debt, the genre of prestige television, and the archic sources of state violence. The contributors were invited to envisage forms of authority which might lie beyond both neoliberalism as an ideology and a set of practices - and the neoliberal state as an ensemble of institutions. They draw on social theory, philosophy, cultural studies, legal geography and political theology in exploring new possibilities for cultivating judgement through and beyond the sovereign, political and aesthetic terrains of neoliberal governance. This struggle for forms of authority beyond the neoliberal state is not a search for a single or synthetic alternative framework, but a challenge to the intellectual orthodoxy during the past four decades which has mandated (even for many on the political left) that 'there is no alternative' to neoliberalism.

Timothy Peters opens the collection with his article 'Corporations, sovereignty and the religion of neoliberalism'. He uncovers the theological origins of neoliberalism and modern economic governance to re-examine our understanding of sovereignty and the corporation, unearthing, via an engagement with Giorgio Agamben (2007, 20II, 2016) and Joshua Barkan (20I3), the resources for a radical consideration of collectivity and sociality. Peters argues that the corporation is not under threat from but rather fundamentally intertwined with state sovereignty, and that the growth of neoliberalism, associated with the growth of corporations, privatisation, and corporatisation, has not diminished but rather intensified state sovereignty. However, rather than further regulating corporations or eliminating corporate personhood, Peters calls for a return to the notion of corporateness that undergirds the theological genealogy of the corporation. In theological accounts of the roots of neoliberalism, and in particular, Catholic Social Teaching, Peters finds modes of sociality that encompass a sense of gratuitousness and reciprocity and are articulated in contrast to the neoliberal modes of the 
state and the contracting individual. In his account, an alternative genealogy of corporateness emerges, unconstrained by notions of sovereignty.

In 'Life is not simply fact: Aesthetics, atmosphere and the neoliberal university', Karin van Marle explores the ways in which neoliberal aesthetics have colonised the space of the university and robbed it of its status as a public good through restricting the curriculum, stifling protest and dissent, and diminishing the possibilities for academic community, intellectual friendship and collegiality. Drawing on the student protests in South Africa during 2015 and 2016 against the increasing of student fees, and Achille Mbembe's work connecting it to broader movements for decolonisation, van Marle identifies the ways in which neoliberalism functions in the university context as a source of epistemic, ontological and spatial injustice - a denial not only of access but of inhabitance, of ways of knowing and being that manifest spatially (Mbembe 2016). Turning to recent critical work on atmosphere as a form of 'new aesthetics', she considers the possibilities for an alternative aesthetic based on bodily presence, sensory experiences, complexity, and slowness, and its potential to counter, rupture and problematise power in the neoliberal university.

Chris Butler returns to the terms of debate over the intimate connections between neoliberalism and state power in his article, 'State power, the politics of debt and confronting neoliberal authoritarianism'. Beginning with a survey of Marxist interpretations of the class character of the neoliberal state and Foucauldian accounts of the production of subjectivity of the individual as an enterprise, Butler introduces the recent work of Maurizio Lazzarato, who has argued that the asymmetrical creditor-debtor relationship is now the archetype of contemporary, neoliberal social relations (Lazzarato 20I2, 20I5). Lazzarato draws on an eclectic range of influences, including Deleuze and Guattari, Nietzsche, Foucault, Marx and Schmitt, but Butler argues that the perspective which results, tends to exaggerate the totalising powers of finance capital. Ultimately, this leads Lazzarato to endorse a form of political voluntarism, which fails to address the role of the neoliberal state as a site for forms of authoritarianism which are not solely generated by the debt relation. Butler concludes by suggesting the possibility of using aspects of Nicos Poulantzas's concept of 'authoritarian statism' to both deepen our understanding of the authoritarian characteristics of the neoliberal state, but also to re-imagine ways of confronting its expressions of power (Poulantzas 2000).

In 'Reproducing whiteness: Feminist genres, legal subjectivity, and the post-racial dystopia of The Handmaid's Tale', Karen Crawley examines the imagining of authority in the context of a dystopian text that has been a significant worldwide site for feminist critique and 
cultural engagement: the 2017 televisual adaptation of The Handmaid's Tale (Miller 2017-). Although the show has been widely understood as a feminist indictment of patriarchy, Crawley's reading focuses on the show's post-racial aesthetic, revealing it to be heavily invested in neoliberal logics, and the universalised subject position of white feminism. She unravels the significance of these ideas for our critical feminist understanding of legal subjectivity and authority under neoliberal conditions. Her account shows how whiteness is reproduced through cultural texts that inculcate particular ways of seeing, and modes of identification and attachment that invite viewers to not see certain forms of racist state violence and white supremacy that persist in liberal democracies like the United States, Canada and Australia. Inhabiting the antipodean viewing position of a white academic living and working on stolen land, her reading of this visual text attempts to connect 'the handmaid's tale' and its vision of liberal legality to these disavowed national and international histories and contexts of state and settler violence, giving necessary context to contemporary feminist struggles for reproductive justice.

The final paper in this collection is James Martel's 'Why does the state keep coming back? Neoliberalism, the state and the archeon'. In this piece, Martel reorients our understanding of neoliberalism by situating it as just one archist political formation among others, such as populism, authoritarianism or Trumpism. Drawing on Derrida, Foucault, and Benjamin, Martel sketches the contours of this archism, a style of politics based on rule and division, and centred upon the 'archeon'; that privileged vantage point from which the state or law can judge, without itself being subject to that judgement. Martel's reading of Foucault goes against the way in which the latter is often invoked as a thinker of the end of sovereignty, arguing that Foucault emphasises the intransigence of archism's ongoing power and validity. He then turns to Walter Benjamin to think about what states do for us and why they continue to survive. For Benjamin, states are the acme of what he calls 'mythic violence', the projection of things that are not true onto the world as a way to control and dominate it. The central object that has no ontological reality is the state and its laws. The state turns to violence, Benjamin says, because it is insecure about its own right to exist. But the subjects of the state are complicit with this too because they yearn for the stability and determination that is promised (but never delivered) by mythic violence. In this way, the state keeps surviving its own death. By looking at how Benjamin subverts the theological origins of the archeon with the idea of a God who abandons the position of judgement, Martel suggests that the necessary response to neoliberalism is an-archism, the form of politics that is oriented explicitly against 
mythic violence and its various archist manifestations, a form of politics that denies the archeon its privileged place.

ACKNOWLEDGEMENTS. As editors of this special issue, we would like to express our appreciation to all the participants at the symposium on 'Forms of Authority Beyond the Neoliberal State' held at the Griffith Law School in December 2017, including Edwin Bikundo, Angela Daly, James Martel, Daniel Matthews, Connal Parsley, Timothy Peters, Daniel McLoughlin and Karin van Marle. We would like to acknowledge the Law Futures Centre at Griffith University for the financial support which made this event possible. Many thanks are also due to the editorial team at Law and Critique, particularly Moniza Rizzini Ansari and Valerie Kelley, who have been very patient with us during the last few months.

\section{REFERENCES}

Agamben, Giorgio. 2007. Profanations, trans. Jeff Fort. New York: Zone Books.

Agamben, Giorgio. 20I I. The kingdom and the glory: For a theological genealogy of economy and government. Stanford: Stanford University Press.

Agamben, Giorgio. 2016. Capitalism as religion. In Agamben and radical politics, ed. Daniel McLoughlin, 15-26. Edinburgh: Edinburgh University Press.

Barkan, Joshua. 2013. Corporate sovereignty: Law and government under capitalism. Minneapolis: University of Minnesota Press.

Barnett, Clive. 2010. Publics and markets: What's wrong with neoliberalism? In The Sage Handbook of social geographies, ed. Susan Smith, et al. London: Sage: 269-296.

Boltanski, Luc, and Eve Chiapello. 2005. The new spirit of capitalism. London: Verso.

Bourdieu, Pierre. 1998. Acts of resistance: Against the tyranny of the market. Cambridge: Polity Press.

Brabazon, Honor. 2017a. Introduction: Understanding neoliberal legality. In Neoliberal legality: Understanding the role of law in the neoliberal project. London: Routledge: I-2I.

Brabazon, Honor, ed. 2017b. Neoliberal legality: Understanding the role of law in the neoliberal project. London: Routledge.

Brown, Wendy. 2015. Undoing the demos: Neoliberalism's stealth revolution. New York: Zone Books

Cahill, Damien. 2014. The end of laissez-faire? On the durability of embedded neoliberalism. Cheltenham: Edward Elgar Publishing.

Dardot, Pierre, and Christian Laval. 20I4. The new way of the world: on neoliberal society. London: Verso. 
Davies, William. 20I4. The limits of neoliberalism: Authority, sovereignty and the logic of competition. London: Sage.

Dean, Jodi. 2008. Enjoying neoliberalism, Cultural Politics 4(I): 47-72.

Duménil, Gérard, and Dominique Lévy. 2004. Capital resurgent: The roots of the neoliberal revolution. Cambridge, Mass.: Harvard University Press.

Foucault, Michel. 2008. The birth of biopolitics: Lectures at the Collège de France 1978-1979. Houndmills, Basingstoke: Palgrave Macmillan

Gilbert, Jeremy. 2013. What kind of thing is 'neoliberalism'?, New Formations 80/8I: 7-22.

Golder, Ben, and Daniel McLoughlin, eds. 2018. The politics of legality in a neoliberal age. London: Routledge.

Harvey, David. 2005. A brief history of neoliberalism. Oxford: Oxford University Press.

Honig, Bonnie. 20I3. The politics of public things: Neoliberalism and the routine of privatization, NoFo 10: 59-76.

Lazzarato, Maurizio. 2012. The making of the indebted man: An essay on the neoliberal condition, trans. Joshua David Jordan, Los Angeles: Semiotext(e).

Lazzarato, Maurizio. 2015. Governing by debt, trans. Joshua David Jordan, South Pasadena: Semiotext(e).

Mbembe, Achille. 2016. Decolonizing the university: New directions, Arts \& Humanities in Higher Education I5(I): 29-45.

Miller, Bruce. (Showrunner). 2017. The handmaid's tale (film version). Hulu.

Mirowski, Philip. 2009. Postscript: Defining neoliberalism. In The road from Mont Pèlerin: The making of the neoliberal thought collective, eds. Philip Mirowski, and Dieter Plehwe. Cambridge, Mass.: Harvard University Press: 4I7-456.

Poulantzas, Nicos. 2000. State, power, socialism. London: Verso.

Peck, Jamie. 200I. Workfare states, New York: Guilford Press.

Passavant Paul. 2005. The strong neo-liberal state: crime, consumption, governance, Theory and Event 8(3): https://muse-jhu-edu.libraryproxy.griffith.edu.au/article// 87839

Peck, Jamie. 20 I0. Constructions of neoliberal reason. Oxford: Oxford University Press.

Peck, Jamie, and Adam Tickell. 2002. Neoliberalizing space, Antipode 34(3): 380-404.

Plant, Raymond. 2010. The neo-liberal state. Oxford: Oxford University Press.

Rose, Nikolas. 1996. The death of the social? Refiguring the territory of government, Economy and Society 25: 327-56. 
Rose, Nikolas, Pat O'Malley, and Mariana Valverde. 2006. Governmentality, Annual Review of Law Society 2: 83-104.

Springer, Simon, Kean Birch, and Julie MacLeavy, eds. 2016. The handbook of neoliberalism London: Routledge. 